\title{
THE INFLUENCE OF BLOOD FLOW AND ARTERIAL BLOOD PRESSURE DURING CARDIOPULMONARY BYPASS ON DELTOID MUSCLE GAS TENSIONS AND BODY TEMPERATURE AFTER BYPASS
}

\author{
Theodore H. STANLEY AND Jesse Jackson
}

SKeLETAL MUSCLE OXYGEN $\left(\mathrm{Pm}_{\mathrm{O}_{2}}\right)$ and carbon dioxide tensions $\left(\mathrm{Pm}_{\mathrm{CO}_{2}}\right)$ are related to muscle perfusion..$^{1-3}$ A recent report from this laboratory demonstrated that both high arterial blood pressure and high flow rate are necessary during cardiopulmonary bypass to ensure muscle perfusion and that utilization of pressors during bypass maintains blood pressure at high levels but at the expense of muscle blood flow. "The question of whether it is desirable to perfuse skeletal muscle during extracorporeal circulation could not be answered by that study. The purpose of this study was to determine the influence of skeletal muscle blood flow during bypass on body temperature after bypass and in the early postoperative period.

\section{METHODS}

The study was approved by the Wilford Hall U.S.A.F. Medical Center Human Study Committee. Informed written consent was obtained from every patient at the preoperative visit. A total of 24 patients scheduled for coronary artery revascularization operations made up the experimental subjects.

Premedication included pentobarbitone $1 \mathrm{mg} \cdot \mathrm{kg}^{-1}$ or diazepam $1 \mathrm{mg} \cdot \mathrm{kg}^{-10}$, morphine $1 \mathrm{mg} \cdot \mathrm{kg}^{-10}$, and atropine $0.05 \mathrm{mg} \cdot \mathrm{kg}^{-10}$ given intramuscularly 90 minutes before the scheduled lime of operation. Preoperative preparation and intra-operative blood and fluid management schedules have been previously described. ${ }^{5.6} \mathrm{~Pa}$ tients were anaesthetized with morphine 1 to $3 \mathrm{mg} \cdot \mathrm{kg}^{-1}$ plus oxygen and paralyzed with succinylcholine $1.5 \mathrm{mg} \cdot \mathrm{kg}^{-1}$. The trachea was then intubated and respiration was controlled to maintain $\mathrm{Pa}_{\mathrm{CO}}$ between 4.66-5.32 kPa (3540 torr) as has been previously described. ${ }^{5.6}$

Theodore H. Stanley, M.D., Professor of Anesthesiology/Surgery; Jesse Jackson, Physician's Assistant. Departments of Anesthesiology. The University of Utah College of Medicine, Salt Lake City, Utah and Wilford Hall, USAF Medical Center, San Antonio, Texas. 277

Temperature was measured with oesophageal and rectal probes attached to a Yellow Springs recording module. After induction of anaesthesia a Scientific Research Instrument Corporation Tefion tissue catheter, previously calibrated in lactated Ringer's solution, was implanted into the right or left deltoid muscle through a 12-gauge catheter inserted percutaneously into the muscle. The teflon catheter was attached to a Medspect MN-8 mass spectrometer which continuously sampled and measured muscle oxygen, carbon dioxide and nitrogen tensions.

The cardiopulmonary bypass system consisted of a Bentley BOS-10 bubble oxygenator and Sarns roller pump and was primed with lactated Ringer's solution. $\mathrm{Pa}_{2}$ was maintained between $19.95-26.6 \mathrm{kPa}$ (150-200 torr) during bypass, $\mathrm{Pa}_{\mathrm{CO}_{2}}$ between $4.66-5.32 \mathrm{kPa}$ (35-40 torr) and oesophageal temperature at $28-30^{\circ} \mathrm{C}$. Patients were randomly assigned to one of these groups at the time of the preoperative visit. Eight patients (group I) had bypass flow rate adjusted every two to five minutes to keep $\mathrm{Pm}_{\mathrm{O}_{2}}$ at pre-bypass values $3.99-4.52 \mathrm{kPa}$ (30-34 torr)). Eight patients (group II) had bypass flow rate adjusted to keep mixed venous (common venous relum at the entrance to the oxygenator) $P \bar{v}_{O_{2}}$ between 4.92-5.72 kPa (37-43 torr) (normal values). The final eight patients (group III) had bypass flow adjusted to maintain $\mathrm{PV}_{\mathrm{O}_{2}}$ between $4.92-4.52 \mathrm{kPa}$ (37-43 torr) but in addition had bypass mean blood pressure increased to $11.97-13.3 \mathrm{kPa}\left(90_{-}\right.$ 100 torr) by a dilute infusion of phenylephrine. No patient received sodium bicarbonate or any other alkali at any time during the investigation.

All patients were warmed through the pump oxygenator to a rectal temperature of $37^{\circ} \mathrm{C}$ at the end of bypass and maintained on a warming blanket set at $39^{\circ} \mathrm{C}$ at the end of bypass and in the postoperative recovery unit. Patients were given pure oxygen to breathe after bypass and during the firsi four hours postoperatively. $\mathrm{PaCO}_{2}$ was maintained between $4.66-5.59 \mathrm{kPa}(35-42$ torr) during these times by appropriate alterations in the mechanical respirator. Rectal temperature, $\mathrm{Pm}_{\mathrm{O}_{2}}, \mathrm{Pm}_{\mathrm{CO}_{2}}, \mathrm{~Pa}_{2}, \mathrm{~Pa}_{\mathrm{CO}_{2}}$, arterial $\mathrm{cH}^{+}(\mathrm{pHa})$ and

Canad. Anaesth. Soc. J., vol. 26, no. 4, July 1979 


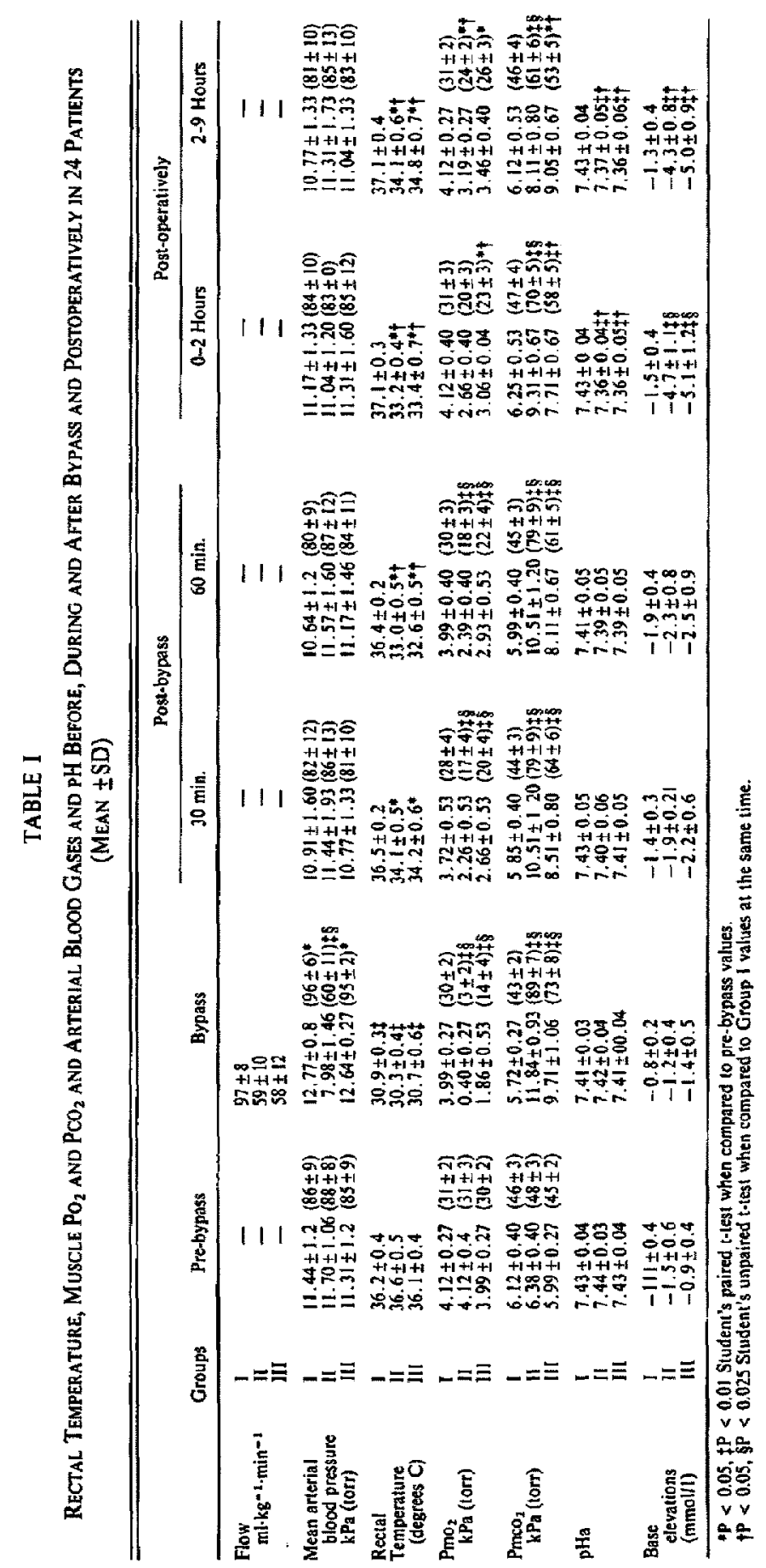


calculated base elevation, using a Severinghaus calculator, were measured before bypass and every 15 minutes during bypass, during the postbypass operative period, and for four hours postoperatively. Blood gas and $\mathrm{pH}$ determinations were made on an Instruments Laboratory blood gas machine and corrections for temperature made using a standard normogram. Values for all variables were averaged* every 30 minutes during and after bypass and every two hours postoperatively. Data were evaluated for statistical significance utilizing Student's paired and unpaired t-tests.

\section{Results}

Mean doses of morphine, arterial blood pressure, cardiac output, rectal and oesophageal temperatures, muscle and arterial gas tensions and arterial $\mathrm{pH}$ and calculated base elevation were similar in the three groups immediately before bypass. Groups I and III had significantly higher and group 11 lower mean arterial blood pressures during bypass than during the prebypass period (Table I). $\mathrm{Pa}_{\mathrm{CO}_{2}}, \mathrm{pHa}$ and calculated base deficit were similar in the three groups during bypass and not significantly different than pre-bypass values. $\mathrm{Pa}_{\mathrm{O}_{2}}$ and rectal and oesophageal temperatures were also similar in the three groups during bypass but significantly lower than pre-bypass values.

$\mathrm{Pm}_{\mathrm{O}_{2}}$ and $\mathrm{Pm}_{\mathrm{CO}_{2}}$ were not significantly different from pre-bypass values at any time during the study in group I. $\mathrm{Pm}_{\mathrm{O}_{2}}$ was markedly reduced and $\mathrm{Pm}_{\mathrm{CO}_{2}}$ increased during bypass, the post-bypass period and up to four hours postoperatively in groups II and III. After rewarming to $37^{\circ}$ at the end of bypass, rectal and oesophageal temperatures decreased and remained reduced for up to four hours postoperatively in groups II and III. In contrast, rectal and oesophageal temperatures in group 1 did not significantly change after bypass or postoperatively. $\mathrm{Pa}_{2}$ and $\mathrm{PaCO}_{2}$ were similar in the three groups during the post-bypass period and up to four hours postoperatively. Arterial pH and base elevation were also similar in the three groups after bypass but were significantly lower in groups II and III than group I in the postoperative period.

* Statistical significance for $\mathrm{pH}$ changes were determined by converting $\mathrm{pH}$ to concentrations of hydrogen ion and then reconverting to $\mathrm{pH}$ after mean, standard deviation, P values, etc., were determined.

\section{Discussion}

Flow rates and arterial blood pressures considered ideal during cardiopulmonary bypass vary a great deal from one cardiopulmonary bypass team to another.* A few years ago we demonstrated that regulating bypass flow rate to ensure a normal mixed venous oxygen tension $\left(\mathrm{P}_{\mathrm{O}_{2}}\right)$ was superior to perfusing at a fixed calculated flow rate based on body surface or weight. ${ }^{2}$ In a recent study we showed that regulation of flow rate during cardiopulmonary bypass to maintain a normal $\mathrm{Pv}_{\mathrm{O}_{2}}$ produced normal arterial and mixed venous $\mathrm{pH}$ but did not ensure a normal $\mathrm{Pm}_{\mathrm{O}_{2}}$ and thus normal perfusion to muscle. ${ }^{4}$ The data in that study indicated that both high arterial pres. sure and flow rate were necessary during bypass to maintain normal muscle perfusion and that utilization of pressor's during bypass maintained high mean arterial blood pressure but at the expense of muscle blood flow. Whether it is desirable to perfuse skeletal muscle during nonpulsatile extracorporeal circulation could not be answered by our previous report. The results of this study demonstrate that skeletal muscle perfusion during bypass prevents decreases in body temperature after end-of-bypass rewarming and avoids impaired skeletal muscle blood flow in the post-bypass and early postoperative periods. Our findings also suggest that skeletal muscle perfusion during bypass decreases the amount of acid metabolites present in the circulation postoperatively.

Although cooling during bypass decreases metabolic and perfusion requirements, it is clear from the marked increases in $\mathrm{Pm}_{\mathrm{CO}_{2}}$ measured in patients in groups II and III in this study, that some skeletal muscle metabolism continues. Absence of marked decreases in perfusion to muscle during and after bypass requires that the acid metabolites produced during these periods will accumulate. Removal of these metabolites will only occur after circulation to muscle is reestablished in the post-bypass and post-operative periods. This was undoubtedly the mechanism which resulted in post-operative decreases in $\mathrm{pH}$ and base elevation in our patients in groups II and III. While the modest decreases in $\mathrm{pH}$ and base elevation observed post-operatively in patients in groups II and III did not appear to have a significant effect on their recovery, this may not be the case in patients with unstable circulatory dynamics. Metabolic acidosis significantly de-

*Garman JK, personal communication. 
creases myocardial inotropy ${ }^{8}$ and could, even in small amounts, result in cardiovascular decompensation in a patient with marginal myocardial mechanics or cardiovascular dynamics.

Decreases in body temperature after bypass and in the early postoperative period in spite of body surface warming are a common problem and can result in depressed respiratory and circulatory dynamics and increased cardiac instability. ${ }^{9.10}$ Our findings in this study suggest that cooling after bypass rewarming may primarily be caused by poor perfusion to, and thus inadequate rewarming of, skeletal muscle at the end of extracorporeal circulation. The use of high flows and arterial pressures (without resorting to vasopressors) ensured skeletal muscle perfusion during bypass and eliminated post-bypass and postoperative cooling. While employment of high pressure and high flow bypass techniques have been criticized because of increased haemolysis, high urine output (and thus electrolyte loss) and risk of particulate and air embolism, ${ }^{1}$ these have not been problems in our hospital. Therefore, high flow-high arterial pressure bypass appears to be a simple technique for avoiding post-bypass and post-operative hypothermia.

\section{SUMMARY}

The results of this study demonstrate that skeletal muscle perfusion during bypass requires high flows and mean arterial pressures and that use of vasopressors during bypass impairs skeletal muscle blood flow. Our findings also indicate that skeletal muscle perfusion during bypass decreases metabolic acidosis after operation and prevents decreases in body temperature and poor skeletal muscle blood flow in the postbypass and early postoperative periods. Our results suggest that perfusing to maintain normal $\mathrm{Pm}_{\mathrm{O}_{3}}$ during extracorporeal circulation is superior to more conventional techniques of conducting bypass.

\section{RÉSUMÉ}

Nous avons étudié l'influence du débit sanguin musculaire durant la circulation extracorporelle sur la température des opérés après la CEC et au cours des premières heures post-opératoires. La circulation musculaire était évaluée par la mesure de la $\mathrm{PO}_{2}$ et de la $\mathrm{PCO}_{2}$ au niveau du deltoïde.

Dans un premier groupe de huit malades, le débit de la CEC a été ajusté de façon à maintenir la $\mathrm{PO}_{2}$ du deltoïde $\left(\mathrm{PM}_{\mathrm{O}_{2}}\right)$ aux valeurs observées avant la CEC, soit 3.9 à $4.5 \mathrm{kPa}(30-34$ torr). Chez huit autres patients (groupe 1I), le débit de CEC a été ajusté de façon à maintenir la $\mathbf{P O}_{2}$ veineuse mixte $\left(\mathrm{PV}_{\mathrm{O}_{2}}\right)$ aux valeurs observées avant la CEC, soit entre 4.92 et $5.72 \mathrm{kPa}$ (37-43 torr). Enfin, un dernier groupe de huit malades (groupe III) a été perfusé comme les patients du groupe Il et, en plus, une perfusion de phényléphrine a été utiljsée chez eux pour maintenir la pression de perfusion entre 11.9 et $13.3 \mathrm{kPa}$ ( 90 à 100 torr). En cours de CEC, les malades ont été refroidis à une température cesophagienne entre $28^{\circ}$ et $30^{\circ} \mathrm{C}$; ils ont tous été réchauffés à une tempémature rectale de $37^{\circ} \mathrm{C}$ en fin de CEC.

La pression artérielle moyenne, le débit cardiaque, les températures rectales et oesophagiennes, ainsi que les gazométries et les $\mathrm{pH}$ artériels et musculaires, étaient comparables chez les malades des trois groupes avant la circulation extracorporelle, La $\mathrm{Pit}_{2}$, la $\mathrm{PaCa}_{2}$, la pHa, l'excès de base calculé, ainsi que les températures rectales et cesophagiennes étaient similaires chez les malades des trois groupes en cours de CEC, mais les patients des groupes I et III avaient une pression de perfusion significativement plus élevée que ceux du groupe Il. La tension de $\mathrm{la}^{\mathrm{PO}_{2}}$ et de la $\mathrm{PCO}_{2}$ au niveau du deltoïde $\left(\mathrm{Pm}_{\mathrm{O}_{2}}\right.$ et $\mathrm{Pm}_{\mathrm{CO}_{2}}$ ) étaient semblables à celles observées avant la CEC au cours de toute la durée de l'étude chez les malades du groupe 1. La $\mathrm{Pm}_{\mathrm{O}_{2}}$ était significativement abaissée, et la $\mathrm{Pm}_{\mathrm{Co}_{2}}$ significativement élevée durant et immédiatement après la CEC, et au cours des quatre premières heures d'observation post-operatoire chez les patients des groupes II et III. Après le réchauffement à $37^{\circ} \mathrm{C}$, en fin de CEC, les températures rectales et cesophagiennes ont diminué et sont demeurées plus basses jusqu'à quatre heures après la fin de la chirurgie chez les patients des groupes II et III: par contre. les températures rectales et cesophagiennes n'ont pas changé de façon significative après la CEC et dans la période post-opératoire immédiate chez les malades du groupe I. $\mathrm{Le}_{\mathrm{cH}}^{+}(\mathrm{pH})$ et l'excès de base artériels étaient semblables dans les trois groupes à la fin de la CEC, mais étaient significativement plus bas dans la phase post-opératoire chez les malades des groupes II et III.

Les résultats de nos iravaux démontrent que le maintien d'une bonne perfusion musculaire en cours de circulation extracorporelle prévient les chutes de température observées après le réchauffement de fin de CEC et prévient l'insuffisance circulatoire dans les masses mus- 
culaires après la CEC et au cours de la phase post-opératoire. Nos observations suggèrent également que la peifusion adéquate des masses musculaires en cours de CEC diminue la quantité de métabolites acides présents dans la circulation durant la phase post-opératoire.

I. Furuse, A., Brawley, R.K., Struve, E. \& GoTr. V.L. Skeletal muscle gas tension: indicator of cardiac output and peripheral tissue perfusion. Surgery $74: 214$ (1973).

2. Fuller, R.M. \& Dos, J.B. Muscle $\mathrm{pH}, \mathrm{PO}_{2}, \mathrm{PCO}_{2}$ monitoring: A review of laboratory and clinical evaluations. Adv. Exp. Biol. 50: 175 (1974).

3. Wakabayoshi, A., Yoshima, N., Woolley, T., Mullin, P.J., Watanabe, H. Takashi, I. \& Connolly, J.E. Continuous percutaneous monitoring of muscle gas $\mathrm{pH}$ and oxygen pressures. Arch. Surg. 110: 802 (1975).

4. STANI.EY, T. H. Arterial pressure and deltoid muscle gas tensions during cardiopulmonary bypass in man. Canad. Anaesth. Soc. J. 25: 286 (1978).

5. Stanley. T. H., Gray, N. H., Stanford, W. \& ARMSTRONG, R. The effects of high-dose morphine on fluid and blood requirements of open-heart operations. Anesthesiology 38: 536 (1973).

6. Stanley, T.H., Gray, N.H., Isern-Amaral,
J.A. \& Patton, C. Comparison of blood requirements during morphine and halothane anesthesia for open-heart surgery. Anesthesiology 4l: 34 (1974).

7. Stanley, T. H. \& Isern-Amaral, J.A. Periodic analyses of mixed venous oxygen tension to monitor the adequacy of perfusion during and after cardiopulmonary bypass. Canad. Anaesth. Soc. J. 2l: 454 (1974).

8. Carson, S. A. A., Chorley, G. E.. Hamil.ton, F. N., LeE, D. O. \& Morris, L.E. Variation in cardiac output with acid-base changes in the anesthetized dog. J. Appl. Physiol. 20:948 (1965).

9. LowENSTEIN, E. \& BLANo, J.H.L. Anesthesia for cardiac surgery, Cardiac Surgery, 2nd ed., ed. by Norman, J.C. New York. Appleton-Century Crofts, 1972, pp. 75-102.

10. VASCo, J.S.\& DEARING, J.P. Perfusion techniques of curdiopulmonary bypass. Cardiac Surgery, 2nd ed. Ed, by Norman, J.C. New York, AppletonCentury Crofts, pp. 133-181 (1972).

11. Hilberman, M., Myers, B., Kolkka, R., GarMEN, J.K., Stofer, R.C., Overton, M.A., StinSON, E. B. \& JAMESON. R. The development of acute renal failure following open-heart surgery with low-flow, low-pressure cardiopulmonary bypass. Abstracts 1977 ASA Meeting. pp. 589 (1977). 